\title{
ANALISIS FENETIK KULTIVAR CABAI BESAR Capsicum annuum L. DAN CABAI KECIL Capsicum frutescens L.
}

\author{
Susi Agustina, Pudji Widodo, HeXa APRILIANA HidAYAH
}

Fakultas Biologi, Universitas Jenderal Soedirman, Jalan dr. Suparno 63 Purwokerto 53122

\section{A B S T R A C T}

A study on the "Phenetic analysis of Capsicum annuum L. and Capsicum frutescens L. " has been conducted from June to August 2012. The aim of the research is to know the relationship amoung big chillis and small chillis based on morphology. The samples were taken from 5 villages in Sukamantri Sub-district, Ciamis. The method used in this research was explorative survey with purposive random sampling. The character data of big chili and small chili morphologies were analyzed descriptively to determine the relationship using UPGMA (Unweighted Pair Group Mean Arithmetic) methods. The result of this study showed that there were seven cultivars of big chilli, namely C. annuum „Hot Chili", Gada, Fantastik, Keriting TM 888, Tanjung 2, Keriting TM 999, Hot Beauty, and four cultivars of small chilli namely C. frutescens "Cakra Ungu", Cakra Hijau, Bendot, and Cakra Putih. The fenogram showed that there were five groups, two groups of $C$. annuum and three groups of $C$. frutescens. The first group consisted of $C$. annuum „Hot Chili", Keriting TM 888, Fantastik, and Tanjung 2. The second group consisted of $C$. annuum "Gada", Hot Beauty, and Keriting TM 999. The third group was C. frutescens „Bendot". The fourth group consisted of $C$. frutescens „Cakra Putih", and C. frutescens „Cakra Hijau". The fifth group was $C$. frutescens „Ungu". The closest relationship was between C. annuum „Keriting TM 999 and C. annuum „Hot Beauty" and the farthest relationship was between $C$. frutescens „Bendot" and C. frutescens „Ungu“"

KEY WORDS: similarity, cultivars, Capsicum annuum, Capsicum frutescens, Sukamantri Sub-district, Ciamis

Penulis korespondensi: SUSI AGUSTINA | email: nchie.agustin@gmail.com

\section{PENDAHULUAN}

Cabai atau lombok merupakan tanaman semak dari famili Solanaceae, berasal dari benua Amerika tepatnya daerah Peru dan menyebar ke negaranegara benua Amerika, Eropa dan Asia termasuk Negara Indonesia. Menurut Hapsari (2011) ada dua cabai yang tumbuh dan ditanam di Indonesia yaitu cabai besar (Capsicum annuum L.) dan cabai rawit (Capsicum frutescens L.). Sosok tanaman dan buah cabai sangat bervariasi, diperkirakan ada 20 spesies yang sebagian besar hidup di negara asalnya (Nawangsih, 1999).

Cabai merupakan tanaman dari anggota genus Capsicum, yang memiliki nama populer di berbagai negara, misalnya chili (Inggris), pimenta (Portugis), chile (Spanyol). Cabai di Indonesia sering disebut dengan berbagai nama lain, misalnya lombok, mengkreng, cengis, cengek, dan masih banyak lagi sebutan lainnya (Prajnanta, 2007). Secara umum cabai memiliki banyak kandungan gizi dan vitamin, diantaranya kalori, protein, lemak, kabohidarat, kalsium, vitamin A, B1 dan vitamin C (Arifin, 2010). Menurut Kemala (2005), cabai juga mengandung lasparaginase dan capsaicin yang berperan sebagai zat anti kanker.

Menurut Hapsari (2011), cabai dapat ditanam dari ketinggian 0-2.000 $\mathrm{m}$ dpl dan dapat beradaptasi dengan baik pada temperatur $24-27^{\circ} \mathrm{C}$ dengan kelembaban yang tidak terlalu tinggi. Nawangsih (1999) menyatakan bahwa tanaman cabai dapat ditanam pada tanah sawah maupun tegalan yang gembur, subur, tidak terlalu liat dan cukup air. Permukaan tanah yang paling ideal adalah datar dengan sudut kemiringan lahan $0-10^{\circ}$ serta membutuhkan sinar matahari penuh dan tidak ternaungi, $\mathrm{pH}$ tanah yang optimal antara 5,5-7. Cabai besar (Capsicum annuum L.) memiliki banyak variasi menurut spesies dan kultivarnya diantaranya Keriting TM999, Keriting TM888, Salero, Taro, Kunthi, Hot Beauty, CTH-01, Long Chili, Hero, Rabu, Maraton, Arimbi-513, Miles Flavor, TW-Keriting-PH94, F1Elegance, F1-Jetset, F1- Spirit, F1-Horison, F1-Restu, F1-Profit, Helix, F1-Princess, F1-Flash 750, F-1 Rimbun, F1-Trophy, Tombak, Cemeti (Hapsari, 2011). Ciri-ciri daunnya ada yang berbentuk membulat telur, melonjong, oval, bahkan ada yang melanset (Wiryanta, 2002). Warna permukaan daun bagian atas hijau muda, hijau tua, sampai hijau kebiruan, sedangkan pada permukaan daun bagian bawah umumnya berwarna hijau, hijau muda, atau hijau pucat. Permukaan daun ada yang halus dan ada yang berkerut-kerut. Panjang daun cabai berkisar antara 3$11 \mathrm{~cm}$, dengan lebar antara 1-5 cm (Zulfitri, 2005). Batang tanaman cabai berwarna hijau muda, atau hijau tua. Akar cabai merupakan akar tunggang yang terdiri atas akar utama dan akar samping yang berupa serabut-serabut akar (Fatmawati, 2008). Bunga berbentuk bintang, tumbuh pada ketiak daun, dalam keadaan tunggal atau bergerombol dalam tandan. Satu tandan biasanya terdapat 2-3 bunga saja. Mahkota bunga warnanya bermacam-macam, ada yang putih, putih kehijauan, dan ungu. Bunga berdiameter antara 5-20 mm, merupakan bunga sempurna, yaitu dalam satu tanaman terdapat bunga jantan dan bunga betina. Buah cabai merupakan bagian tanaman cabai yang paling banyak dikenal dan memiliki banyak variasi misalnya bentuk seperti lonceng atau bell (Prajnanta, 2007).

Nama cabai kecil (Capsicum frutescens L.) di daerah Jawa lebih dikenal dengan sebutan cabe rawit. Kultivar cabai rawit bermacam-macam diantaranya cabai mini, cabai ceplik (rawit putih), cabai cengis 
(rawit hijau), dan lombok japlak (Setiadi, 1997). Ciriciri morfologi yang mencolok adalah batang berbukubuku atau bagian atasnya bersudut, daun berbentuk melonjong atau membundar telur, panjang 1-12 cm, tulang daun menyirip, letak bunga berdekatan. Mahkota bunga membintang, berwarna putih kehijauan atau kadang- kadang ungu, bunga biasanya menggantung, mempunyai garis tengah 1,75-2 mm. Kelopak bunga umumnya berbulu tetapi ada pula yang tidak berbulu, mempunyai panjang 2-3 mm berwarna kehijauan. Buah tegak, kadang-kadang pada tanaman hibrid buah menggantung, berbentuk bulat telur, jorong dengan diameter 0,75-1,50 mm, panjang 2,5-12 cm. Buah muda berbeda-beda warnanya ada yang berwarna hijau tua, hijau muda, ungu, hitam, putih, putih kekuningan, ketika setengah masak warnanya juga berbeda-beda ada yang hijau, cokelat kemerahan, dan setelah masak buah berwarna merah, hitam, ungu kehitaman (Setiadi, 2006).

Hubungan kesamaan kultivar kedua cabai tersebut belum banyak diketahui sehingga perlu dianalisis hubungan kesamaannya. Morfologi yang nampak pada suatu tumbuhan umumnya dapat digunakan untuk menentukan hubungan kekerabatan antar spesies tumbuhan. Istilah kekerabatan dalam taksonomi secara umum mencakup dua pengertian yaitu hubungan kekerabatan fenetik dan hubungan kekerabatan filogenetik (evolusi). Kekerabatan filogenetik ditentukan berdasarkan asal usul nenek moyang tumbuh-tumbuhan sesuai dengan perkembangan atau proses evolusi (Davis dan Heywood, 1973). Kekerabatan fenetik adalah hubungan kekerabatan yang didasarkan pada penampakan morfologi (Shukla dan Misra, 1982).

Tingkat kekerabatan dan kesamaan tergantung pada macam, sifat dasar dan interpretasi dari koefisien karakter yang digunakan. Menurut Jones dan Luchsinger (1987), karakter untuk menyusun klasifikasi didapatkan dari berbagai sifat tumbuhan. Semua bagian tumbuhan dapat digunakan sebagai karakter. Karakter juga dapat dikumpulkan dari berbagai bidang antara lain anatomi, polinologi, dan kimia. Tjitrosoepomo (1992) menyatakan bahwa untuk mengetahui hubungan kekerabatan suatu tumbuhan perlu dilakukan pencandraan tumbuhan tersebut. Deskripsi merupakan hal penting dan mutlak yang harus dilakukan karena pencandraan adalah suatu uraian mengenai bentuk dan susunan tumbuhan beserta organ-organnya dengan ciri masing-masing.

Analisis fenetik akan menghasilkan klasifikasi fenetik yang merupakan kesamaan (similaritas) dari individu dengan pertimbangan berdasarkan satu set fenotip (karakter yang berhubungan dengan kenampakan). Tingkat kekerabatan dari kesamaan tergantung pada macam, sifat dasar dan interpretasi dari koefisien karakter yang digunakan (Shukla dan Misra, 1982). Penentuan jauh dekatnya hubungan kekerabatan fenetik antar takson tumbuhan satu sama lain adalah dengan cara menentukan persamaan atau kesamaan antar takson tersebut secara berpasangan (Dunn dan Everit, 1982). Nilai yang terdapat dalam masing-masing pasangan yang membentuk diagram adalah nilai yang menunjukkan besarnya persamaan sifat antara dua spesies yang berpasangan. Jika dua spesies yang berpasangan mempunyai nilai 1 berarti keduanya sama, sebaliknya jika nilai 0 berarti keduanya berbeda (Clifford and Stephenson, 1975).

Penelitian tentang analisis fenetik kultivar cabai besar dan cabai kecil ini dilakukan di Kecamatan Sukamantri Kabupaten Ciamis. Kabupaten Ciamis memiliki luas 2.553,71 km2, terletak di bagian tenggara Jawa Barat. Kecamatan Sukamantri merupakan salah satu dari 36 kecamatan yang berada di wilayah Kabupaten Ciamis. Adapun batas-batas Kecamatan Sukamantri adalah sebagai berikut: Sebelah Utara berbatasan dengan Kabupaten Majalengka, Sebelah Timur berbatasan dengan Kecamatan Panawangan, Sebelah Selatan berbatasan dengan Kecamatan Lumbung dan Panjalu, Sebelah Barat berbatasan dengan Kecamatan Panjalu dan Panumbangan (BP3K, 2012a).

Kecamatan Sukamantri terdiri atas 5 desa yaitu Cibeureum, Mekarwangi, Sindanglaya, Sukamantri, Tenggerraharja dengan luas wilayah 47,9 km² (BP3K, 2012a). Keadaan iklim di Kecamatan Sukamantri adalah suhu udara $17-26^{\circ} \mathrm{C}$, curah hujan rata-rata $2.500 \mathrm{~mm}$ dengan jumlah bulan hujan rata-rata enam bulan per tahun, dan ketinggian 600-900 m dpl. Karakteristik lahan di wilayah Kecamatan Sukamantri mempunyai spesies tanah latosol yang mempunyai tingkat keasaman sebagaian besar agak masam, sedangkan kemiringan tanah antara 15\% sampai dengan 39\%. Dengan demikian lahan yang ada di Kecamatan Sukamantri tofografinya bergelombang sampai berbukit dan sebagian dataran rendah sehingga cocok untuk tanaman sayuran terutama cabai diantaranya cabai besar dan cabai kecil (BP3K, 2012a). Karena masih minimnya data tentang hubungan kesamaan antara 2 spesies cabai tersebut dan dengan adanya cabai hibrida sehingga perlu dilakukan penelitian tentang analisis fenetik cabai besar dan cabai kecil di Kecamatan Sukamantri Kabupaten Ciamis. Berdasarkan uraian di atas, dapat dirumuskan permasalahan sebagai berikut: Bagaimana hubungan kesamaan cabai besar dan cabai kecil berdasarkan morfologi di Kecamatan Sukamantri.Berdasarkan perumusan masalah tersebut, penelitian ini bertujuan untuk: Mengetahui hubungan kesamaan cabai besar dan cabai kecil berdasarkan morfologi di Kecamatan Sukamantri.

Dengan dilakukannya penelitian ini diharapkan diperoleh data mengenai hubungan kesamaan cabai besar dan cabai kecil di Kecamatan Sukamantri sehingga dapat dijadikan informasi dalam upaya pengelolaan, pengembangan potensi, serta pemanfaatan cabai besar dan cabai kecil khususnya bagi ilmu pengetahuan dan bagi masyarakat pada umumnya. 


\section{MET ODE}

Bahan yang digunakan dalam penelitian ini adalah cabai besar dan cabai kecil yang ada di Kecamatan Sukamantri. Alat-alat yang digunakan dalam penelitian adalah alat tulis, kamera, gunting, pisau, penggaris, kertas label, kertas dupleks, kertas koran dan kantong plastik.

Penelitian ini dilakukan di wilayah Kecamatan Sukamantri, Kabupaten Ciamis yang meliputi 5 desa, yaitu: Cibeureum, Mekarwangi, Sindanglaya, Sukamantri, Tenggerraharja. Penelitian ini dilaksanakan pada bulan Juli hingga Agustus 2012.

Penelitian dilakukan dengan menggunakan metode survai eksploratif dan teknik pengambilan sampel dilakukan secara acak terpilih (Purposive Random Sampling) 5 desa di Kecamatan Sukamantri. Dilakukan pengambilan sampel tanaman cabai besar dan cabai kecil yang terdapat 5 desa di Kecamatan Sukamantri, yaitu: Cibeureum, Mekarwangi, Sindanglaya, Sukamantri, Tenggerraharja dan didokumentasikan berupa foto. Sampel tumbuhan (batang, daun, bunga, buah, dan biji) diambil dari lapangan kemudian diamati morfologi dan dicatat. Khusus bagian daun, sampel daun diambil daun kelima dari ujung. Karakter morfologi yang diamati sebanyak 33 karakter dimasukkan dalam tabel untuk analisis kekerabatan fenetik. Sampel diidentifikasi dengan pustaka sesuai Backer and Bakhuizen, (1965), Arifin, (2010), Fatmawati, (2008), Nawangsih, (1999), Prajnanta, (2007), Piay et al, (2010), Setiadi (1997), dan Setiadi, (2006). Sifat-sifat morfologi yang diperoleh dari pengamatan dan pengukuran ditabulasikan ke dalam tabel untuk dianalisis dengan software MEGA 5.0 (Tamura et al., 2010). Sampel selanjutnya dibuat herbarium dan disimpan di Herbarium Universitas Jenderal Soedirman (PUNS) sebagai acuan dimasa yang akan datang. Kunci identifikasi dibuat berdasarkan data morfologi.

Cabai besar dan cabai kecil yang ditemukan dianalisis hubungan fenetiknya berdasarkan sifat morfologinya, sedangkan data morfologi dianalisis dengan UPGMA menggunakan software MEGA 5.0 (Tamura et al., 2010). Cara analisis data adalah sebagai berikut:

1. Menetapkan sifat dari semua karakter yang ada dengan angka $0,1,2$, dan 3 .

2. Dimasukkan dalam tabel di microsoft excel.

3. Dicopy paste ke microsoft word kemudian dimerge.

4. Direplace 0 menjadi A, 1 menjadi T, 2 menjadi G, dan 3 menjadi $\mathrm{C}$.

5. Dicopy paste ke software MEGA.
6. Memilih phylogeny kemudian bootstrap test of phylogeny.

7. Memilih UPGMA dan akan terlihat fenogram yang terbentuk.

8. Melihat indeks diskesamaan dengan memilih distance kemudian compute pairwise.

\section{HASIL DAN PEMBAHASAN}

Berdasarkan penelitian yang telah dilakukan di Kecamatan Sukamantri Kabupaten Ciamis yang terdiri dari lima desa ditemukan tujuh kultivar cabai besar (Capsicum annuum L.) yaitu C. annuum "Hot Chili", C. annuum "Gada", C. annuum "Fantastik", C. annuum "Keriting TM 888", C. annuum "Tanjung 2", C. annuum "Keriting TM 999", C. annuum "Hot Beauty", dan empat kultivar cabai kecil (Capsicum frutescens L.) yaitu C. frutescens "Ungu", C. frutescens "Cakra Hijau", C. frutescens "Bendot", dan C. frutescens "Cakra Putih" (Tabel 3.1). C.annuum L. "Gada" merupakan kultivar paling banyak ditemukan (frekuensı11) di 5 desa yang terdapat di Kecamatan Sukamantri. Hasil survei diperoleh bahwa masyarakat di Kecamatan Sukamantri lebih banyak menyukai kultivar cabai besar "Gada" dibandingkan kultivar cabai besar lainnya. Hal ini dikarenakan pohonnya mudah tumbuh, daging buahnya tidak terlalu tebal, warnanya merah dan rasanya pedas. Masyarakat Kecamatan Sukamantri terutama kelompok tani banyak yang membudidayakannya, serta memperjualbelikan hasil panen cabai mereka. Selain itu, kelompok tani tersebut telah bekerja sama dengan PT. ABC untuk menjual hasil panen mereka dengan masa panen 3 minggu sekali. Menurut Fatmawati (2008), dari hasil penelitiannya di Subang menyatakan bahwa produktivitas buah C.annuum L. „Gada” saat panen sekitar 13,65 ton/ha dan bobot buah pertanaman 533,33 gr.

Berdasarkan survei, kultivar $C$. frutescens L. "Ungu” paling sedikit ditemukan (frekuensi < 5) hanya ditemukan di Desa Cibeureum dan Sindanglaya. Kultivar cabai ini kebanyakan digunakan sebagai tanaman hias walaupun sebagian ada yang digunakan untuk bumbu masak.

Tabel 1. Jumlah individu Capsicum annuum L. dan Capsicum frutescens L.yang ditemukan di Kecamatan Sukamantri, Kabupaten Ciamis.

\begin{tabular}{|c|c|c|c|c|c|c|}
\hline \multirow{2}{*}{ No } & \multirow{2}{*}{ Spesies Capsicum } & \multicolumn{5}{|c|}{ Desa } \\
\hline & & A & $\mathrm{B}$ & $\mathrm{C}$ & $\mathrm{D}$ & $\mathrm{E}$ \\
\hline 1. & Capsicum annuum L. "Hot Chili” & $* *$ & $* *$ & $*$ & $* *$ & $* *$ \\
\hline 2. & Capsicum annuum L. "Gad" & $* * *$ & $* *$ & $* * *$ & $* * *$ & ** \\
\hline 3. & Capsicum annuum L. "Fantastik" & $* *$ & $* *$ & $* *$ & $*$ & $*$ \\
\hline 4. & Capsicum annuum L. "Keriting TM888" & $* *$ & $* *$ & $* *$ & $* *$ & $* *$ \\
\hline 5. & Capsicum annuum L. “Tanjung 2" & $*$ & * & $*$ & $*$ & $*$ \\
\hline 6. & Capsicum annuum L. "Keriting TM999" & $* * *$ & $* *$ & $* *$ & $* * *$ & $* *$ \\
\hline 7. & Capsicum annuum L. "Hot Beauty" & $* *$ & $*$ & $* *$ & $* *$ & $* *$ \\
\hline 8. & Capsicum frutescens L. "Ungu” & $* *$ & $\mathrm{x}$ & $*$ & $\mathrm{x}$ & $\mathrm{x}$ \\
\hline 9. & Capsicum frutescens L. "Cakra Hijau" & $* * *$ & $* *$ & $* *$ & $* *$ & $* *$ \\
\hline 10. & Capsicum frutescens L. "Bendot"' & $*$ & $*$ & $\mathrm{x}$ & $*$ & $*$ \\
\hline 11. & Capsicum frutescens L. "Cakra Putih" & $* *$ & $*$ & $* *$ & $*$ & $* *$ \\
\hline
\end{tabular}

Keterangan: A. Cibeureum, B. Mekarwangi, C. Sindanglaya, D. Sukamantri, E. Tenggerraharja

$\mathrm{x}=$ Tidak ditemukan, ${ }^{*}=$ Jarang ditemukan (frekuensi tiap lokasi $\left.\leq 6\right),{ }^{* *}=$ Sedang (frekuensi tiap lokasi 7-10),

*** = Melimpah (frekuensi tiap lokasi $\geq 11$ ) 
Hal ini yang menyebabkan masyarakat di Kecamatan Sukamantri tidak terlalu antusias menanam tanaman cabai tersebut, masyarakat belum begitu banyak mengetahui manfaat cabai ungu tersebut serta bibitnya juga sulit untuk diperoleh.

Kunci Identifikasi cabai besar Capsicum annuum L. dan cabai kecil Capsicum frutescens L. yang ditemukan di Kecamatan Sukamantri Kabupaten Ciamis.

1. a. Tanaman musiman, buah panjang $(>10 \mathrm{~cm}) \ldots \ldots \ldots \ldots . . . . .2$

b. Tanaman tahunan, buah pendek $(<10 \mathrm{~cm})$................... 8

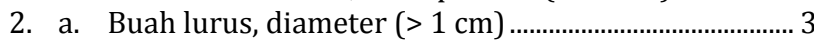

b. Buah keriting diameter $(<1 \mathrm{~cm})$.................................. 4

3. a. Diameter buah $1,5-1,7 \mathrm{~cm}$, Rasa sangat pedas............... ...Capsicum annuum L. "Hot Chili"

b. Diameter buah $1-1,5 \mathrm{~cm}$, rasa pedas Capsicum annuum L. "Gada"

4. a. Warna daun muda hijau muda ........................................ 5

b. Warna daun muda hijau tua ........................................... 7

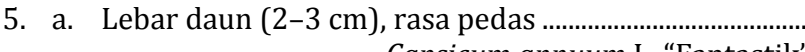
Capsicum annuum L. "Fantastik"

b. Lebar daun (1-1,5 cm), rasa sangat pedas Capsicum annuum L. "Keriting TM888"

6. a. Lebar daun $(>1,8 \mathrm{~cm})$, buah lurus Capsicum annuum L. "Tanjung 2"

b. Lebar daun $(<1,8 \mathrm{~cm})$, buah keriting ............................ 6

7. a. Tangkai daun hijau tua, rasa buah sangat ........................ Capsicum annuum L. "Keriting TM 999"

b. Tangkai daun hijau muda, rasa buah tidak . Capsicum annuum L. "Hot Beauty"

8. a. Warna batang ungu, warna daun permukaan atas hijau keunguan

..Capsicum frutescens L. "Ungu"

b. Warna batang hijau tua, warna permukaan atas hijau tua

.... 9

9. a. Bentuk buah seperti gasing tebal dan pendek.. .. Capsicum frutescens $\mathrm{L}$. "Bendot"

b. Bentuk buah lurus memanjang, langsing dan Panjang

10. a. Urutan perkembangan warna buah hijau, masak cokelat kemerahan

Capsicum frutescens L. "Cakra Hijau”

b. Urutan perkembangan warna buah putih

kekuningan, orange, merah

Capsicum frutescens L. "Cakra Putih"

Capsicum annuum L. "Hot Chili"

C. annuum L. "Hot Chili" merupakan cabai merah hibrida berupa semak dengan tinggi tanaman 91-105 cm. Diameter batang berkisar antara 1-1,5 cm, berwarna hijau tua dengan bentuk batang berbuku-buku. Bentuk daun melanset, panjang 6-13 cm, lebar 2-3,5 cm. Tata letak daun berseling. Bagian ujung dan pangkal daun meruncing. Permukaan daun halus, warna tangkai daun hijau muda, dengan panjang 4-5 $\mathrm{cm}$. Tepi daun rata, jumlah tulang daun samping 3-5 buah. Warna permukaan daun bagian atas hijau tua, sedangkan warna permukaan daun bagian bawah hijau muda. Warna daun muda hijau muda sedangkan warna daun tua cokelat tua sampai kehitaman. Arah tumbuh bunga ke bawah. Warna kelopak bunga hijau dan warna mahkota bunga putih. Jumlah mahkota bunga umumnya 5 kadang-kadang 6 helai. Buah lurus, arah tumbuh buah ke bawah, dengan ujung buah runcing. Panjang buah 14-15 cm, diameter buah 1,5-1,7 cm. Warna buah muda hijau tua, warna buah setengah masak cokelat kemerahan sedangkan warna buah yang sudah masak berwarna merah dan rasanya sangat pedas. Diameter biji berukuran 3-4 mm. Warna biji muda putih kekuningan dan warna biji tua cokelat tua (Gambar 1). Distribusi: di semua Desa di Kecamatan Sukamantri.

\section{Capsicum annuum L. 'Gada'}

C. annuum L. „Gada" merupakan cabai merah hibrida berupa semak dengan tinggi tanaman 70-104 cm. Diameter batang berkisar antara 1-1,5 cm, berwarna hijau tua dengan bentuk batang berbuku-buku. Bentuk daun melanset, panjang 6-13 $\mathrm{cm}$, lebar 2-3 cm. Tata letak daun berseling. Bagian ujung dan bagian pangkal daun meruncing. Permukaan daun halus, warna tangkai daun hijau tua, dengan panjang 4-5 $\mathrm{cm}$. Tepi daun rata, jumlah tulang daun samping 3-6 buah. Warna permukaan daun bagian atas hijau tua, sedangkan warna permukaan daun bagian bawah hijau muda. Warna daun muda hijau tua sedangkan warna daun tua cokelat tua sampai kehitaman. Arah tumbuh bunga ke bawah. Warna kelopak bunga hijau dan warna mahkota bunga putih. Jumlah mahkota bunga umumnya 5 kadang-kadang 6 helai. Buah lurus, arah tumbuh buah ke bawah, dengan ujung buah runcing. Panjang buah $20-23 \mathrm{~cm}$, diameter buah 1-1,5 $\mathrm{cm}$. Warna buah muda hijau tua, warna buah setengah masak cokelat kemerahan sedangkan warna buah yang sudah masak berwarna merah dan rasanya pedas. Diameter biji berukuran 3-4 mm. Warna biji muda putih kekuningan dan warna biji tua cokelat tua (Gambar 2).

\section{Capsicum annuum L. 'Fantastik'}

C. annuum L. „Fantastik" merupakan cabai merah hibrida berupa semak dengan tinggi tanaman 87-95 cm. Diameter batang berkisar antara 1-1,5 cm, berwarna hijau tua dengan bentuk batang berbuku-buku. Bentuk daun melanset, panjang 6-13 cm, lebar 2-3 cm. Tata letak daun berseling. Bagian ujung dan bagian pangkal daun meruncing. Permukaan daun halus, warna tangkai daun hijau tua, dengan panjang 4-5 $\mathrm{cm}$. Tepi daun rata, jumlah tulang daun samping 3-5 buah. Warna permukaan daun bagian atas hijau tua, sedangkan warna permukaan daun bagian bawah hijau muda. Warna daun muda hijau muda sedangkan warna daun tua cokelat tua sampai kehitaman. Arah tumbuh bunga ke bawah. Warna kelopak bunga hijau dan warna mahkota bunga putih. Jumlah mahkota bunga umumnya 5 kadang-kadang 6 helai. Buah lurus, arah tumbuh buah ke bawah dengan ujung buah runcing. Panjang buah 15-17 cm, diameter buah 1-1,3 cm. Warna buah muda hijau tua, warna buah setengah masak cokelat kemerahan sedangkan warna buah yang sudah masak berwarna merah dan rasanya pedas. Diameter biji berukuran 3-4 $\mathrm{mm}$. Warna biji muda putih kekuningan dan warna biji tua cokelat tua (Gambar 3). Distribusi : di semua Desa di Kecamatan Sukamantri.

\section{Capsicum annuum L. 'Keriting TM 888'}

C. annuum L. „Keriting TM 888 merupakan cabai merah hibrida berupa semak dengan tinggi tanaman $65-95 \mathrm{~cm}$. Diameter batang berkisar antara 1-1,3 cm, berwarna hijau tua dengan bentuk batang berbuku-buku. Bentuk daun melanset, panjang 6-13 cm, lebar 1-1,5 cm. Tata letak daun berseling. Bagian ujung dan bagian pangkal daun meruncing. Permukaan daun halus, warna tangkai daun hijau tua, dengan panjang 4-5 cm. Tepi daun rata, jumlah tulang daun samping 3-5 buah. Warna permukaan daun bagian atas hijau tua, sedangkan warna permukaan daun bagian bawah hijau muda. Warna daun muda hijau tua sedangkan warna daun tua cokelat tua sampai kehitaman. Arah tumbuh bunga ke bawah. Warna kelopak bunga hijau dan warna mahkota bunga putih. Jumlah mahkota bunga umumnya 5 kadang-kadang 6 helai. Buah keriting, arah tumbuh buah ke bawah dengan ujung buah runcing. Panjang 
buah 11-13 cm, diameter buah 0,8-1,1 cm. Warna buah muda hijau tua, warna buah setengah masak cokelat kemerahan sedangkan warna buah yang sudah masak berwarna merah dan rasanya sangat pedas. Diameter biji berukuran 3-4 mm. Warna biji muda putih kekuningan dan warna biji tua cokelat tua (Gambar 4). Distribusi : di semua Desa di Kecamatan Sukamantri.

\section{Capsicum annuum L. 'Tanjung 2'}

C. annuum L. „Tanjung 2 merupakan cabai merah lokal berupa semak dengan tinggi tanaman $48-55 \mathrm{~cm}$. Diameter batang berkisar antara 1-1,3 cm, berwarna hijau tua dengan bentuk batang berbuku-buku. Bentuk daun melanset, panjang 6-13 cm, lebar 1-1,6 cm. Tata letak daun berseling. Bagian ujung dan bagian pangkal daun meruncing. Permukaan daun halus, warna tangkai daun hijau muda, dengan panjang 4-5 cm. Tepi daun rata, jumlah tulang daun samping 3-5 buah. Warna permukaan daun bagian atas hijau tua, sedangkan warna permukaan daun bagian bawah hijau muda. Warna daun muda hijau tua sedangkan warna daun tua cokelat tua sampai kehitaman. Arah tumbuh bunga ke bawah. Warna kelopak bunga hijau dan warna mahkota bunga putih. Jumlah mahkota bunga umumnya 5 kadangkadang 6 helai. Buah lurus, arah tumbuh buah ke bawah dengan ujung buah runcing. Panjang buah $10-11,5 \mathrm{~cm}$, diameter buah 1-1,2 cm. Warna buah muda hijau tua, warna buah setengah masak cokelat kemerahan sedangkan warna buah yang sudah masak berwarna merah dan rasanya pedas. Diameter biji berukuran 3-4 mm. Warna biji muda putih kekuningan dan warna biji tua cokelat tua (Gambar 5). Distribusi : di semua Desa di Kecamatan Sukamantri.

\section{Capsicum annuum L. 'Keriting TM 999'}

C. annuum L. „Keriting TM 999 merupakan cabai merah hibrida berupa semak dengan tinggi tanaman $65-95 \mathrm{~cm}$. Diameter batang berkisar antara 1-1,3 cm, berwarna hijau tua dengan bentuk batang berbuku-buku. Bentuk daun melanset, panjang 6-13 cm, lebar 1-1,6 cm. Tata letak daun berseling. Bagian ujung dan bagian pangkal daun meruncing. Permukaan daun halus, warna tangkai daun hijau tua, dengan panjang 4-5 cm. Tepi daun rata, jumlah tulang daun samping 3-5 buah. Warna permukaan daun bagian atas hijau tua, sedangkan warna permukaan daun bagian bawah hijau muda. Warna daun muda hijau tua sedangkan warna daun tua cokelat tua sampai kehitaman. Arah tumbuh bunga ke bawah. Warna kelopak bunga hijau dan warna mahkota bunga putih. Jumlah mahkota bunga umumnya 5. kadangkadang 6 helai. Buah keriting, arah tumbuh buah ke bawah, dengan ujung buah runcing. Panjang buah 11,5-13,5 cm, diameter buah 0,8-1,1 cm. Warna buah muda hijau tua, warna buah setengah masak cokelat kemerahan sedangkan warna buah yang sudah masak berwarna merah dan rasanya sangat pedas. Diameter biji berukuran 3-4 mm. Warna biji muda putih kekuningan dan warna biji tua cokelat tua (Gambar 6). Distribusi: di semua Desa di Kecamatan Sukamantri.

\section{Capsicum annuum L. 'Hot Beauty'}

C. annuum L. „Hot Beauty" merupakan cabai merah hibrida berupa semak dengan tinggi tanaman 87-95 cm. Beradaptasi dengan baik di dataran rendah sampai sedang dengan ketinggian 1-600 m dpl (Piay et al, 2010). Diameter batang berkisar antara 1-1,5 cm, berwarna hijau tua dengan bentuk batang berbuku-buku. Bentuk daun melanset, panjang 6-13 cm, lebar 1-1,6 cm. Tata letak daun berseling. Bagian ujung dan pangkal daun meruncing. Permukaan daun halus, warna tangkai daun hijau muda, dengan panjang
4-5 cm. Tepi daun rata, jumlah tulang daun samping 3-6 buah. Warna permukaan daun bagian atas hijau tua, sedangkan warna permukaan daun bagian bawah hijau muda. Warna daun muda hijau tua sedangkan warna daun tua cokelat tua sampai kehitaman. Arah tumbuh bunga ke bawah. Warna kelopak bunga hijau dan warna mahkota bunga putih. Jumlah mahkota bunga umumnya 5 kadangkadang 6 helai. Buah keriting, arah tumbuh buah ke bawah dengan ujung buah runcing. Panjang buah $11-14 \mathrm{~cm}$, diameter buah 1-1,2 cm. Warna buah muda hijau tua, warna buah setengah masak cokelat kemerahan sedangkan warna buah yang sudah masak berwarna merah dan rasanya tidak pedas. Diameter biji berukuran 3-4 mm. Warna biji muda putih kekuningan dan warna biji tua cokelat tua (Gambar 7). Distribusi: di semua Desa di Kecamatan Sukamantri.

\section{Capsicum frutescens $\mathrm{L}$. 'Ungu'}

C. frutescens L. „Ungu“ merupakan cabai kecil berupa semak dengan tinggi tanaman 50-67 cm. Diameter batang berkisar antara 1-1,3 cm, berwarna ungu dengan bentuk batang berbuku-buku. Bentuk daun melanset, panjang 6-8 $\mathrm{cm}$, lebar $2-4 \mathrm{~cm}$. Tata letak daun berseling. Bagian ujung dan bagian pangkal daun meruncing. Permukaan daun halus, warna tangkai daun ungu kehitaman, dengan panjang 4-5 $\mathrm{cm}$. Tepi daun rata, jumlah tulang daun samping 3-5 buah. Warna permukaan daun bagian atas ungu kehitaman, sedangkan warna permukaan daun bagian bawah hijau. Warna daun muda hijau keunguan sedangkan warna daun tua cokelat tua sampai kehitaman. Arah tumbuh bunga ke atas. Warna kelopak bunga hijau dan warna mahkota bunga ungu. Jumlah mahkota bunga 5 helai. Buah berbentuk tombak, arah tumbuh buah ke atas, dengan ujung buah tumpul. Panjang buah 2-3 cm, diameter buah $1-1,5 \mathrm{~cm}$. Warna buah muda ungu kehitaman, warna buah setengah masak cokelat kemerahan sedangkan warna buah yang sudah masak berwarna merah dan rasanya pedas. Diameter biji berukuran 3-4 mm. Warna biji muda putih kekuningan dan warna biji tua cokelat tua (Gambar 8). Distribusi: terdapat di Desa Cibeureum, Sindanglaya di Kecamatan Sukamantri.

\section{Capsicum frutescens $\mathrm{L}$. 'Bendot'}

C. frutescens L. „Bendő̈ merupakan cabai kecil berupa semak dengan tinggi tanaman 50-67 cm. Diameter batang berkisar antara 1-1,3 cm, berwarna hijau tua dengan bentuk batang berbuku-buku. Bentuk daun melanset, panjang 6-8 $\mathrm{cm}$, lebar 2-4 $\mathrm{cm}$. Tata letak daun berseling. Bagian ujung dan bagian pangkal daun meruncing. Permukaan daun halus, warna tangkai daun hijau tua, dengan panjang 3-4 $\mathrm{cm}$. Tepi daun rata, jumlah tulang daun samping 3-5 buah. Warna permukaan daun bagian atas hijau tua, sedangkan warna permukaan daun bagian bawah hijau muda. Warna daun muda hijau muda sedangkan warna daun tua cokelat tua sampai kehitaman. Arah tumbuh bunga ke bawah (mengangguk). Warna kelopak bunga hijau dan warna mahkota bunga putih. Jumlah mahkota bunga 5 helai. Buah berbentuk gasing pendek, tebal pendek. Arah tumbuh buah ke bawah, dengan ujung buah tumpul. Panjang buah $4-5 \mathrm{~cm}$, diameter buah 1-2,5 cm. Warna buah muda hijau muda, warna buah setengah masak cokelat kemerahan sedangkan warna buah yang sudah masak berwarna merah dan rasanya pedas. Diameter biji berukuran 3-4 mm. Warna biji muda putih kekuningan dan warna biji tua cokelat tua (Gambar 9). Distribusi: terdapat di Desa Cibeureum, Mekarwangi, Sukamantri, Tenggerraharja di Kecamatan Sukamantri. 


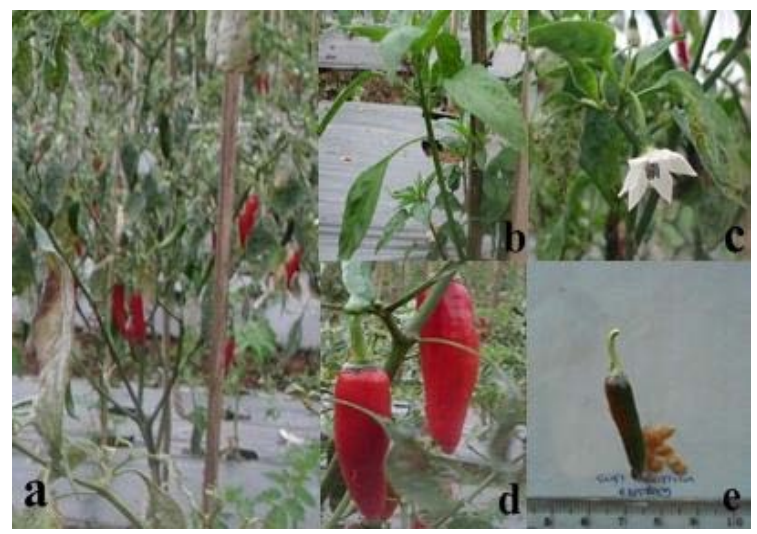

Gambar 1. C. annuum L. „Hot Chili" (a) semak, (b) daun, (c) bunga, (d) buah, (e) biji

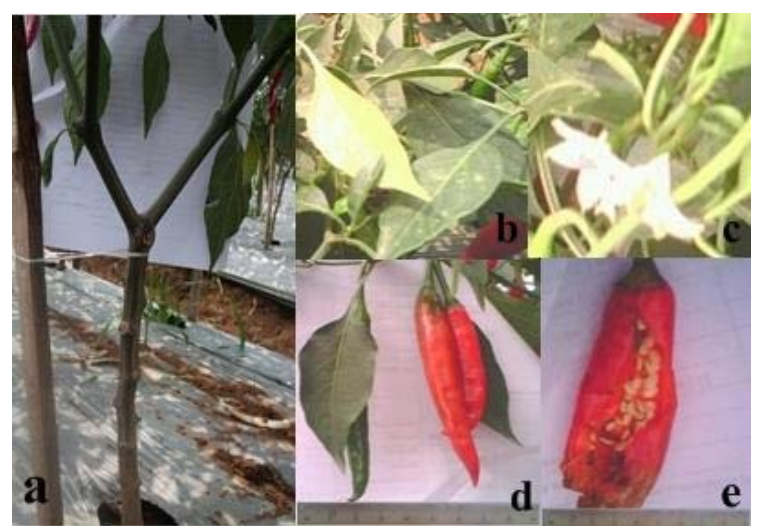

Gambar 2. C. annuum L. „Gada" (a) semak,(b) daun, (c) bunga, (d) buah, (e) biji

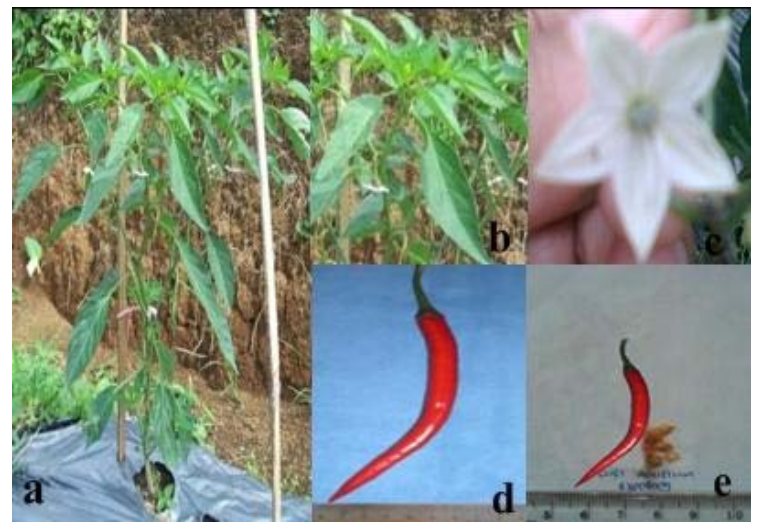

Gambar 3. C. annuum L. „Fantastik" (a) pohon, (b) daun, (c) bunga, (d) buah, (e) biji

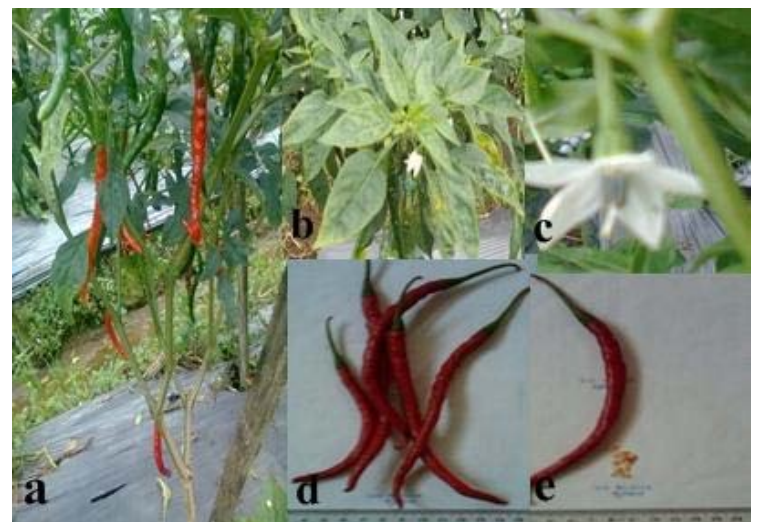

Gambar 4. C. annuum L. Keriting TM 888" (a) pohon, (b) daun, (c) bunga, (d) buah, (e) biji

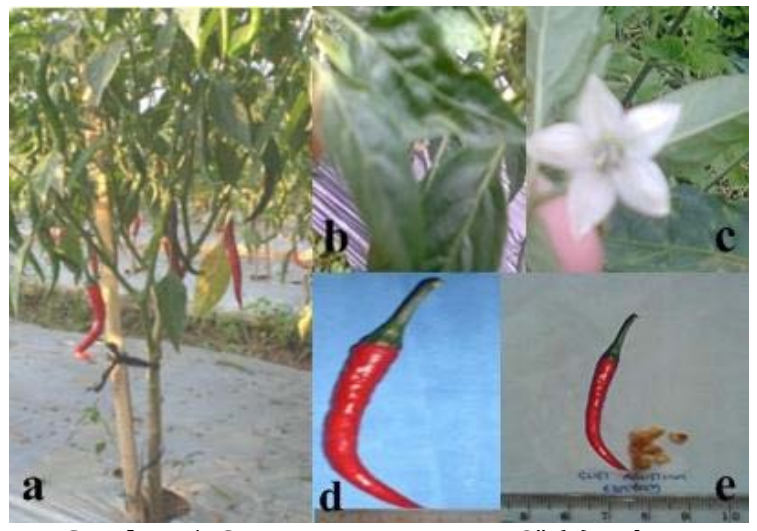

Gambar 5. C. annuum L. „Tanjung 2" (a) pohon,

(b) daun, (c) bunga, (d) buah, (e) biji

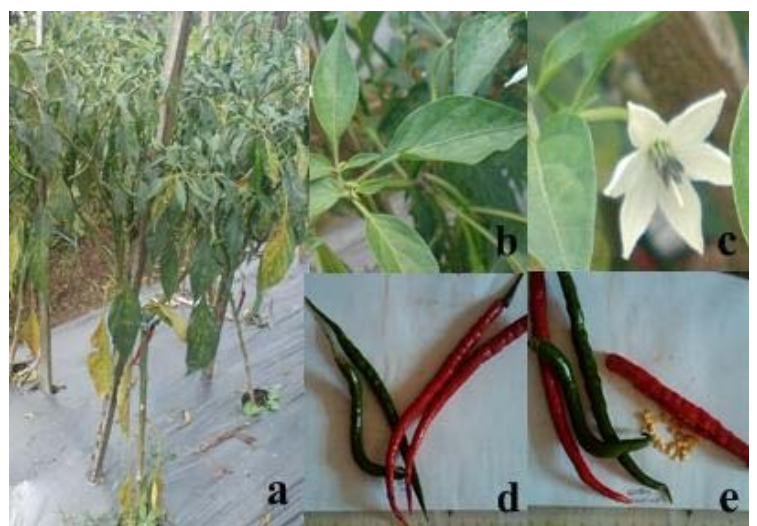

Gambar 6. C. annuum L. Keriting TM 999" (a) pohon, (b) daun, (c) bunga, (d) buah, (e) biji

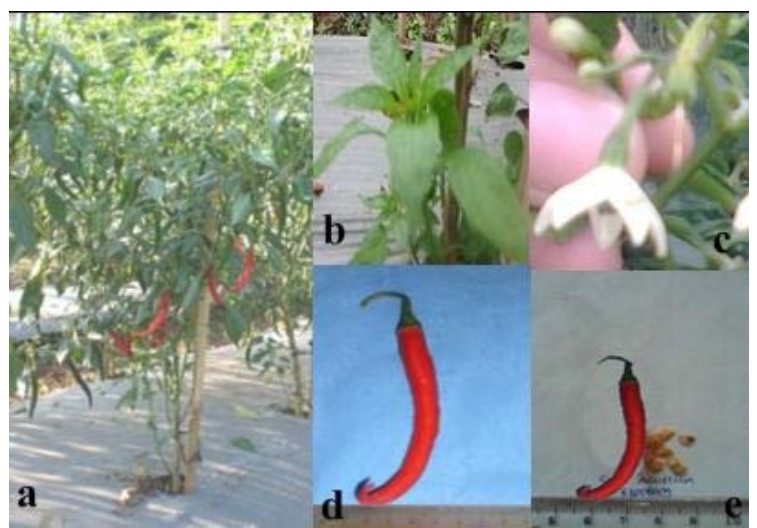

Gambar 7. C. annuum L. „Hot Beauty" (a) semak, (b) daun, (c) bunga, (d) buah, (e) biji

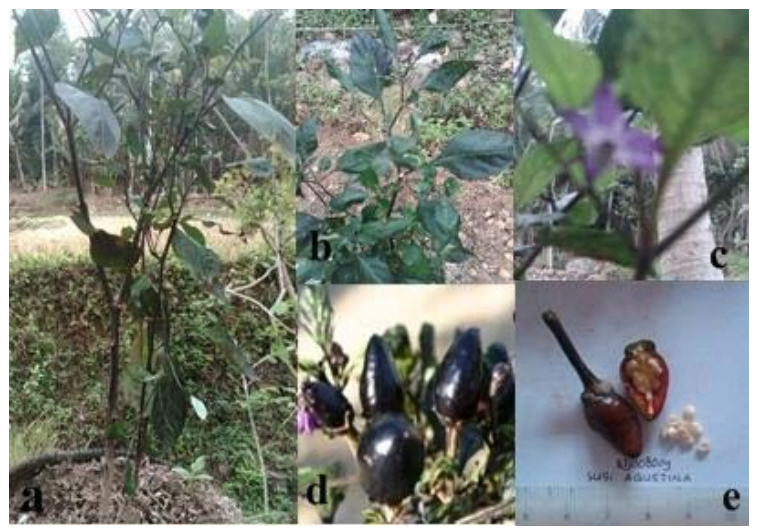

Gambar 8. C. frutescens L. „Ungu“ (a) semak,

(b) daun, (c) bunga, (d) buah, (e) biji 


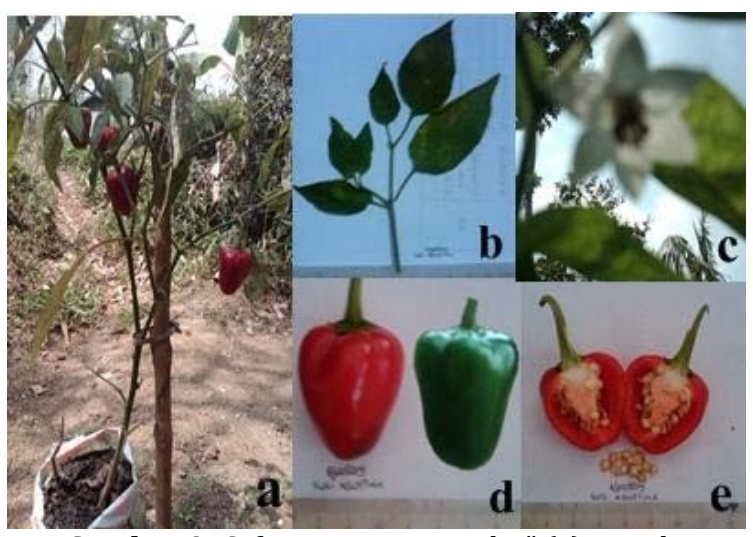

Gambar 9. C. frutescens L. „Bendot" (a) semak,

(b) daun, (c) bunga, (d) buah, (e) biji

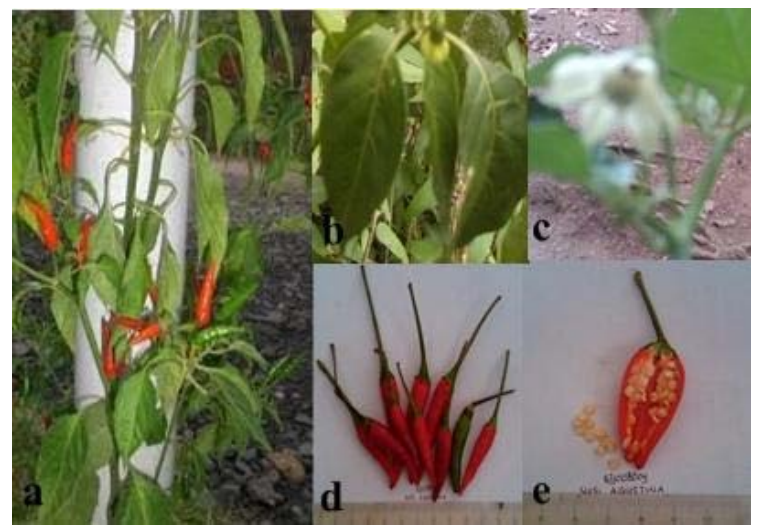

Gambar 10. C. frutescens L. „Cakra Hijau“ (a) semak,

(b) daun, (c) bunga, (d) buah, (e) biji

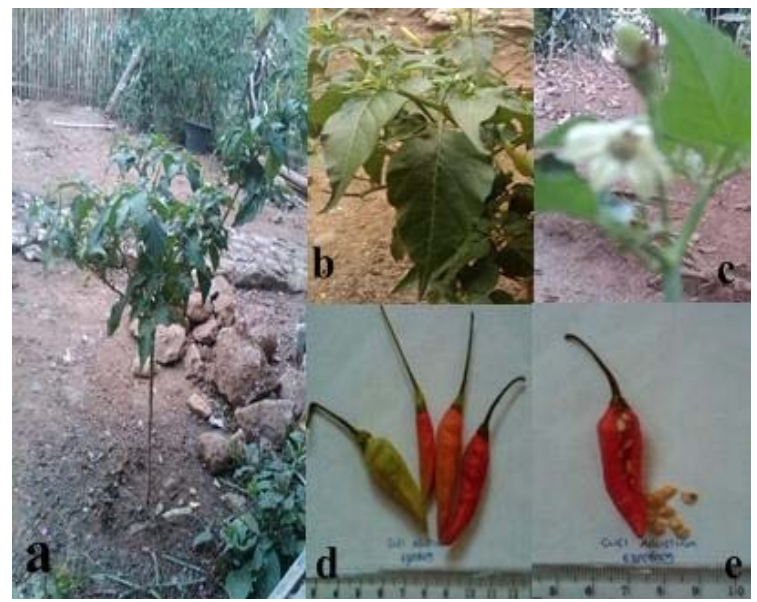

Gambar 11. C. frutescens L. „Cakra Putih" (a) semak,

(b) daun, (c) bunga, (d) buah, (e) biji

Capsicum frutescens $\mathrm{L}$. 'Cakra Hijau'

C. frutescens L. „Cakra Hijaü merupakan cabai cabai kecil berupa semak dengan tinggi tanaman 60-110 cm. Diameter batang berkisar antara 1-1,3 cm, berwarna hijau dengan bentuk batang berbuku-buku. Bentuk daun melanset, panjang 5-8 cm, lebar 2-4 cm. Tata letak daun berseling. Bagian ujung dan bagian pangkal daun meruncing. Permukaan daun halus, warna tangkai daun hijau muda, dengan panjang 3-4 cm. Tepi daun rata, jumlah tulang daun samping 3-5 buah. Warna permukaan daun bagian atas hijau tua, sedangkan warna permukaan daun bagian bawah hijau muda. Warna daun muda hijau muda sedangkan warna daun tua cokelat tua sampai kehitaman. Arah tumbuh bunga ke atas. Warna kelopak bunga hijau dan warna mahkota putih. Jumlah mahkota bunga 5 helai. Buah berbentuk lurus memanjang, langsing dan panjang. Arah tumbuh buah ke atas, dengan ujung buah runcing. Panjang buah 3-4 cm, diameter buah 0,7-1 cm. Warna buah muda hijau tua, warna buah setengah masak cokelat kemerahan sedangkan warna buah yang sudah masak berwarna merah dan rasanya sangat pedas. Diameter biji berukuran 3-4 $\mathrm{mm}$. Warna biji muda putih kekuningan dan warna biji tua cokelat tua (Gambar 10). Distribusi : di semua Desa di Kecamatan Sukamantri.

\section{Capsicum frutescens L. 'Cakra Putih"}

C. frutescens L. „Cakra Putih"“" merupakan cabai kecil berupa semak dengan tinggi tanaman $60-110 \mathrm{~cm}$. Diameter batang berkisar antara 1-1,3 cm, berwarna hijau tua dengan bentuk batang berbuku-buku. Bentuk daun melanset, panjang 5-8 $\mathrm{cm}$, lebar $2-4 \mathrm{~cm}$. Tata letak daun berseling. Bagian ujung dan bagian pangkal daun meruncing. Permukaan daun halus, warna tangkai daun hijau muda, dengan panjang 3-4 $\mathrm{cm}$. Tepi daun rata, jumlah tulang daun samping 3-5 buah. Warna permukaan daun bagian atas hijau tua, sedangkan warna permukaan daun bagian bawah hijau muda. Warna daun muda hijau muda sedangkan warna daun tua cokelat tua sampai kehitaman. Arah tumbuh bunga ke atas. Warna kelopak bunga hijau dan warna mahkota bunga putih. Jumlah mahkota bunga 5 helai. Buah berbentuk lurus memanjang, langsing dan panjang. Arah tumbuh buah ke atas, dengan ujung buah runcing. Panjang buah 3-4 cm, diameter buah 0,7-1 cm. Warna buah muda putih kekuningan, warna buah setengah masak oranye kemerahan sedangkan warna buah yang sudah masak berwarna merah dan rasanya sangat pedas. Diameter biji berukuran 3-4 mm. Warna biji muda putih kekuningan dan warna biji tua cokelat tua (Gambar 11). Distribusi : di semua Desa di Kecamatan Sukamantri.

Berdasarkan data karakter dan sifat morfologi dari Capsicum annuum L. dan Capsicum frutescens L. yang ditemukan di Kecamatan Sukamantri Kabupaten Ciamis, maka diperoleh matriks dissimilaritas karakter morfologi seperti disajikan pada Tabel 2 . Dari Tabel 2 tersebut diketahui bahwa kesamaan terdekat yaitu antara C. annuum „Keriting TM 999 dengan C. annuum „Hot Beautÿ, dengan indeks dissimilaritas 0,03110. Hal ini dikarenakan memiliki ketidaksamaan yang paling sedikit yaitu dari 33 karakter hanya satu karakter yang berbeda. yaitu rasa. Rasa C. annuum „Keriting TM 999" sangat pedas dan rasa $C$. annuum „Hot Beauty“ tidak pedas.

Kesamaan yang paling jauh yaitu antara $C$. frutescens „Ungu“ dengan C. frutescens „Bendot" dengan indeks dissimilaritas 0,31435. Hal ini terjadi karena memiliki ketidaksamaan banyak yaitu dari 33 karakter ada 10 karakter yang berbeda. Sepuluh karakter tersebut adalah warna batang, warna tangkai daun, warna daun permukaan atas, warna daun permukaan bawah, warna daun muda, arah tumbuh bunga, warna kelopak, warna mahkota, arah tumbuh buah, dan warna buah muda.

Dari hasil analisis UPGMA menggunakan softwere MEGA 5.01 diperoleh fenogram kesamaanC. annuum $L$. dan $C$. frutescens $L$. yang ditemukan di Kecamatan Sukamantri Kabupaten Ciamis (Gambar 12). 
Tabel 2. Matriks dissimilaritas karakter morfologi Capsicum annuum L. dan Capsicum frutescens L. yang ditemukan di Kecamatan Sukamantri Kabupaten Ciamis.

\begin{tabular}{|c|c|c|c|c|c|c|c|c|c|c|c|}
\hline & 1 & 2 & 3 & 4 & 5 & 6 & 7 & 8 & 9 & 10 & 11 \\
\hline \multicolumn{12}{|l|}{ 1. Capsicum annuum L. 'Hot Chili' } \\
\hline 2. Capsicum annuum L. 'Hot Beauty' & 0,03112 & & & & & & & & & & \\
\hline 3. Capsicum annuum L. 'Gada' & 0,03114 & 0,03112 & & & & & & & & & \\
\hline 4. Capsicum annuum L. 'Keriting TM 999' & 0,03112 & 0,03110 & 0.03112 & & & & & & & & \\
\hline 5. Capsicum annuum L. 'Keriting TM 888 ' & 0,03114 & 0,03112 & 0,03112 & 0,03114 & & & & & & & \\
\hline 6. Capsicum annuum L. 'Fantastik' & 0,03114 & 0,03112 & 0,03114 & 0,03112 & 0,03114 & & & & & & \\
\hline 7. Capsicum annuum L. 'Tanjung 2' & 0,03114 & 0,03112 & 0,03114 & 0,03112 & 0,03114 & 0,03114 & & & & & \\
\hline 8. Capsicum frutescens L.' Cakra putih' & 0,04761 & 0,04759 & 0,04761 & 0,04759 & 0,04761 & 0,04761 & 0,04761 & & & & \\
\hline 9. Capsicum frutescens L.' Ungu' & 0,28273 & 0,27271 & 0,28273 & 0,27271 & 0,28273 & 0,28273 & 0,28273 & 0,02992 & & & \\
\hline 10. Capsicum frutescens L.'Bendot' & 0,06276 & 0,06276 & 0,06276 & 0,06276 & 0,06276 & 0,06276 & 0,06276 & 0,07923 & 0,31435 & & \\
\hline 11. Capsicum frutescens L.'Cakra Putih' & 0,04761 & 0,04759 & 0,04761 & 0,04759 & 0,04761 & 0,04761 & 0,04761 & 0,06408 & 0,02992 & 0,07923 & \\
\hline
\end{tabular}

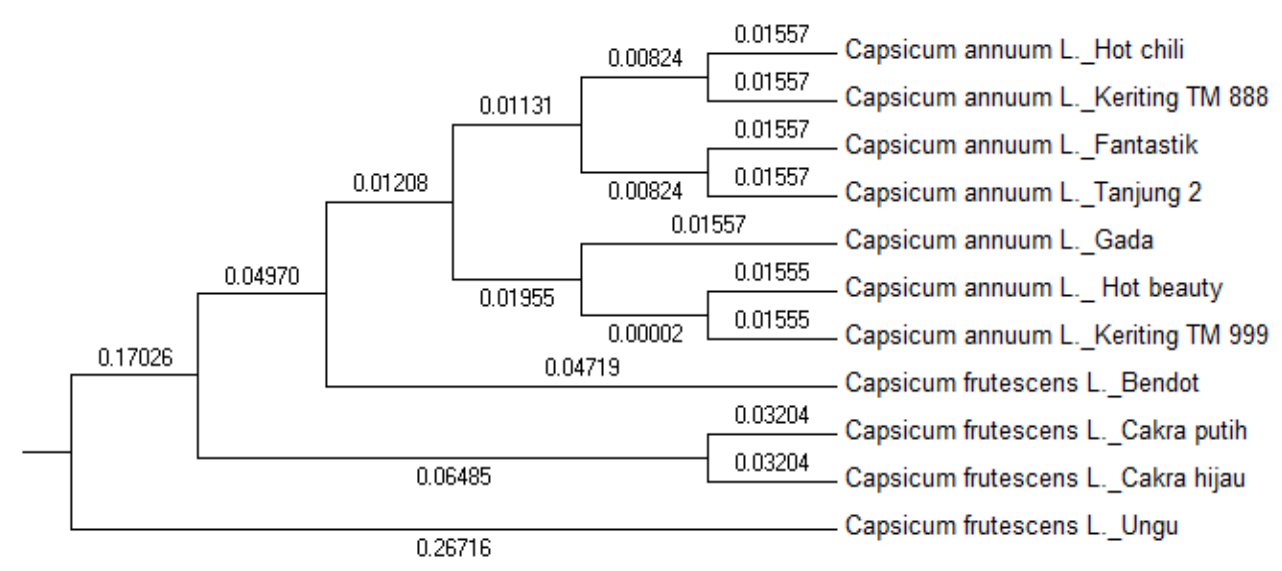

Gambar 12. Fenogram Kesamaan Capsicum annuum L. dan Capsicum frutescens L. yang Ditemukan Di Kecamatan Kecamatan Sukamantri Kabupaten Ciamis Berdasarkan Tes UPGMA dengan Software MEGA 5.01.

Berdasarkan fenogram di atas didapat lima kelompok kesamaan, dua kelompok C. annuum L. dan tiga kelompok C. frutescens. Kelompok I terdiri dari $C$. annuum „Hot Chili", „Keriting TM 888, Fantastik, dan Tanjung 2, persamaan pada kelompok ini yaitu batangnya berwarna hijau tua dengan bentuk batang berbuku- buku, bentuk daun melanset, lebar 2-3 cm, tata letak daun berseling, panjang daun 6-13 cm, bagian ujung dan bagian pangkal daun meruncing, permukaan daun halus, panjang tangkai daun $4-5 \mathrm{~cm}$, tepi daun rata. Warna permukaan daun bagian atas hijau tua, sedangkan warna permukaan daun bagian bawah hijau muda. Warna daun tua cokelat tua sampai kehitaman, arah tumbuh bunga ke bawah, warna kelopak bunga hijau dan warna mahkota bunga putih, arah tumbuh buah ke bawah, dengan ujung buah runcing. Warna buah muda hijau tua, warna buah setengah masak cokelat kemerahan sedangkan warna buah yang sudah masak berwarna merah. Diameter biji berukuran 3-4 mm, warna biji muda putih kekuningan, warna biji tua cokelat tua. Perbedaan morfologi yang mencolok yaitu tinggi $C$. annuum „Hot Chili" 91-120 cm, Keriting TM 888 65-95 cm, Fantastik 87-95 cm, dan Tanjung $248-55 \mathrm{~cm}$. Panjang buah $C$. annuum „Hot Chili" 14-15 cm, Keriting TM 888 11-13 cm, Fantastik 15-17 cm, dan Tanjung "210 -11,5 cm. Diameter buah $C$. annuum „Hot Chili 1,5 $-1,7 \mathrm{~cm}$, Keriting TM 888 0,8-1,1 cm, Fantastik 1-1,3 cm, dan
Tanjung 2 1-1,2 cm. Rasa C. annuum „Hot Chili" dan Keriting TM 888 sangat pedas, sedangkan Fantastik, dan Tanjung 2 pedas.

Kelompok II terdiri dari C. annuum „Gada", Hot Beauty" dan Keriting TM 999, persamaan pada kelompok ini yaitu batangnya berwarna hijau tua dengan bentuk batang berbuku-buku, bentuk daun melanset, tata letak daun berseling, bagian ujung dan bagian pangkal daun meruncing, permukaan daun halus, panjang tangkai daun $4-5 \mathrm{~cm}$, tepi daun rata. Warna permukaan daun bagian atas hijau tua, sedangkan warna permukaan daun bagian bawah hijau muda. Warna daun muda hijau tua, warna daun tua cokelat tua sampai kehitaman, arah tumbuh bunga ke bawah, warna kelopak bunga hijau dan warna mahkota bunga putih. Arah tumbuh buah ke bawah, dengan ujung buah runcing. Warna buah muda hijau tua, warna buah setengah masak cokelat kemerahan sedangkan warna buah yang sudah masak berwarna merah dan rasanya sangat pedas. Diameter biji berukuran 3-4 mm, warna biji muda putih kekuningan, warna biji tua cokelat tua. Perbedaan morfologi yang mencolok yaitu tinggi $C$. annuum „Gada" 70-104 cm, Keriting TM 999 65-95 cm, Hot Beauty 87-95 cm.

Panjang buah C. annuum „Gada" 20-23 cm, Hot Beauty 11-14 cm, Keriting TM 999 11,5-13,5 cm. Diameter buah Gada 1-1,5 cm, Keriting TM 999 0,8-1,1 
cm, Hot Beauty 1-1,2 cm. Rasa C. annuum „Gada" pedas, Hot Beauty tidak pedas, Keriting TM 999 sangat pedas. Kelompok III hanya terdiri dari $C$. frutescens „Bendot". Kelompok ini terpisah karena memiliki ciri khas karakter morfologi yang berbeda dari spesiesspesies Capsicum frutescens L.lainnya yang ditemukan yaitu warna tangkai daun hijau tua, arah tumbuh buah kebawah dengan ujung buah tumpul, panjang buah 4$5 \mathrm{~cm}$, diameter buah 1-2,5 cm. Kelompok IV terdiri dari C. frutescens „Cakra Putih", dan Capsicum frutescens „Cakra Hijăı keduanya mempunyai persamaan tinggi 50-65 cm, warna batang hijau tua, bentuk batang berbuku-buku, bentuk daun melanset, panjang daun 5-8, lebar daun 2-4, tata letak daun berseling, ujung daun dan pangkal daun meruncing, permukaan daun halus, warna tangkai daun hijau muda, panjang tangkai daun 3-4 cm, tepi daun rata, jumlah tulang daun samping 3-5 buah, warna permukaan atas hijau tua, warna permukaan bawah hijau muda, warna daun muda hijau muda, warna daun tua cokelat kehitaman, arah tumbuh bunga ke atas, warna kelopak bunga hijau, warna mahkota bunga putih, arah tumbuh buah ke atas, ujung buah runcing, panjang buah 2-3 cm, diameter buah 0,7-1 $\mathrm{cm}$, warna buah masak merah, rasa sangat pedas, diameter biji 3- $4 \mathrm{~mm}$, warna biji muda putih kekuningan dan warna biji tua cokelat tua. Perbedaan morfologinya terletak pada warna buah muda $C$. frutescens „Cakra Putih" putih sedangkan Cakra Hijau hijau tua dan warna buah setengah masak $C$. frutescens „Cakra Putih“" orange kemerahan sedangkan Cakra Hijau cokelat kemerahan. Kelompok V hanya terdiri dari C. frutescens „Ungu“. Kelompok ini terpisah karena memiliki ciri khas karakter morfologi yang berbeda dari spesies-spesies Capsicum frutescens $\mathrm{L}$. lainnya yang ditemukan yaitu warna batang ungu kehitaman, warna tangkai daun ungu kehitaman, warna daun permukaan atas ungu kehitaman, warna daun permukaan bawah hijau, warna daun muda hijau keunguan, arah tumbuh bunga keatas, warna kelopak bunga hijau keunguan, warna mahkota bunga ungu, ujung buah tumpul, warna buah muda ungu kehitaman dan rasanya pedas.

\section{KESIMPULAN DAN SARAN}

Berdasarkan hasil dan pembahasan, dapat disimpulkan sebagai berikut: Kesamaan terdekat yaitu antara C. Annuum „Keriting TM 999" dengan C. annuum „Hot Beauty". Kesamaan yang paling jauh yaitu antara C. Frutescens „Bendot" dengan $C$. frutescens „Ungu“.

Saran yang dapat diberikan yaitu perlu dilakukan penelitian secara anatomi dan molekuler untuk mengetahui hubungan kesamaan antara Capsicum annuum L. Dan Capsicum frutescens L. Secara lebih mendalam.

\section{AF T AR REFERENSI}

Arifin I. 2010. Pengaruh Cara dan Lama penyimpanan Terhadap Mutu Cabai Rawit (Capsicum frutescens L. var. Cengek) [skripsi]. Universitas Islam Negeri (UIN) Maulana Malik Ibrahim-Malang.

Backer CA, Bakhuizen RC VDB. 1965. Flora of Java (Spermatophytes only). Vol. II. Groningen, Netherlands: Walter Noordhoff N.V.

Laporan Topografi Kecamatan Sukamantri, Ciamis. 2012. BP3K (Balai Penyuluhan Pertanian, Perikanan, dan Kehutanan) Kabupaten Ciamis.

Clifford HT, Stephenson W. 1975. An Introduction to Numerical Classification. London: Academic Press.

Davis PH, Heywood. 1973. Principle of Angiospermae Taxonomy. London: Oliver and Boyd.

Dunn G, Everitt S. 1982. An Introduction to Mathematical Taxonomy. Cambridge: Cambridge University Press.

Fatmawati S. 2008. Evaluasi Daya Hasil Sembilan Hibrida Cabai (Capsicum annuum L.) Di Subang [skripsi]. Institut Pertanian Bogor-Bogor.

Hapsari DT. 2011. Panduan Budidaya Cabai Sepanjang Musim di Sawah dan Pot. Yogyakarta: Trimedia Pustaka.

Jones SB, Luchsinger. 1987. Plant and Systematics. New York: McGraw Hill Book Company.

Kemala S. 2005. Balai Penelitian Tanaman Rempah dan Obat Badan Penelitian dan Pengembangan Departemen Pertanian. Proyek/Bagian Proyek Pengkajian Teknologi Pertanian Partisipatif/PAATP; Laporan Akhir.

Nawangsih A. 1999. Cabai Hot Beauty. Jakarta: Penebar Swadaya,

Prajnanta F. 2007. Agribisnis Cabai Hibrida. Jakarta: Penebar Swadaya,.

Piay SS, Ariarti T, Yuni E, Rudi PH. 2010. Budidaya dan Pascapanen Cabai Merah Capsicum annuum L. BPTP Jawa Tengah (Ungaran).

Setiadi. 1997. Bertanam Cabai. Jakarta: Penebar Swadaya.

Setiadi. 2006. Cabai Rawit Jenis dan Budaya. Jakarta: Penebar Swadaya.

Shukla P, Misra SP. 1982. An Introduction to Taxonomy of Angiosperm. New Delhi: Vicas Publishing House PUT LTD.

Tamura K, Peterson D, Peterson N, Stecher G, Nei M, Kumar S. 2011. MEGA5: Molecular Evolutionary Genetic Analysis Using Maximum Likelihood, Evolutionary Distance, and Maximum Parsimony Methods. Molecular Biology and Evolution, 28:27312739.

Tjitrosoepomo G. 1992. Morfologi Tumbuhan. Yogyakarta: Gadjah Mada University Press.

Wiryanta BTW. 2002. Bertanam Cabai Musim Hujan. Jakarta: Agromedia Pustaka.

Zulfitri. 2005. Analisis Varietas dan Polybag Terhadap Pertumbuhan Serta Hasil Cabai (Capsicum annuum L.) Sistem Hidroponik. Universitas Mercubuana; Buletin penelitian [diakses tanggal 12 April 2012]. Jakarta Barat. 